\title{
Cultural Barriers to Husband's Involvement in Maternal Health in Indonesia Rural Area, A Qualitative Study
}

\author{
Syarifah Syarifah ${ }^{1,2 *}$, Kintoko Rochadi $^{1}$ D, Tukiman Tukiman $^{1}$ (D) \\ ${ }^{1}$ Department of Health Education and Behavioral Sciences, Faculty of Public Health, Universitas Sumatera Utara, Medan, \\ Indonesia; ${ }^{2}$ Centre for Gender and Child Study, Universitas Sumatera Utara, Medan, Indonesia
}

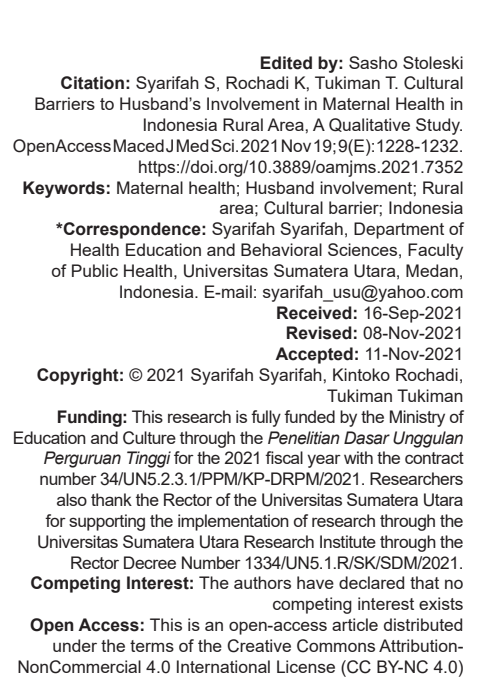

\section{Abstract}

BACKGROUND: Maternal mortality represents the health condition of the mother during pregnancy. In developing countries, maternal health is often poor because pregnant women are not fully supported by their husbands. The problem is, husbands have cultural barriers to engage in activities that can provide space for pregnant women to be healthier.

AIM: This study was conducted to examine the husband's cultural barriers in the Toba Batak culture in North Sumatra, Indonesia.

METHODS: The research was conducted using a qualitative approach in rural areas. A total of 30 husbands were interviewed using Focus Group Discussion (FGD) techniques, in addition to FGDs with health workers.

RESULTS: This study reveals the root of cultural problems related to the husband's perception of men's and women's work, as well as the inherent traditions that make the husband distance himself from maternal health.

CONCLUSION: Cultural barriers of husband's involvement in maternal health are very clear in Batak tribe. Efforts are needed to change cultural barrier by implementing a cultural approach.

\section{Introduction}

The husband's role in reproductive health, especially when the wife is pregnant, is very important [1]. If a husband plays a good role, then a healthier wife will certainly be realized. Unfortunately, there are still many husbands who are not involved in maternal health, which is reflected in the high level of maternal mortality, poor maternal and child health, which generally occurs in low-middle income countries [2], [3], [4].

Therefore, efforts to increase the role of husbands in maternal health are an absolute necessary condition. However, to increase this role, it is not easy, because the husband's reluctance is often very closely related to the cultural views in the community where men and women are raised and live [5], [6]. Both men and women are faced with a patrilineal cultural view, which is implemented in so many social systems of society. This cultural view unfortunately often produces views, mindsets, values, and even practices that prevent husbands from being able to be more actively involved in their wife's health during pregnancy. Investigation of these cultural perceptions can provide information in designing behavior change.
Indonesia has a high maternal mortality rate, even the highest in an Asian country, at 305/100 thousand live births [7]. If we look at the data, among all provinces that make the main contribution, there are only nine (9) provinces that make a significant contribution. One of the nine is North Sumatra Province. The dominant ethnic group in this province is the Batak tribe, who inhabits more than three quarters of the area in North Sumatra Province [8]. Indirectly, as a tribe with a very strong patrilineal tradition, maternal health issues are closely related to the views of the Batak tribe. Therefore, this paper aims to describe the cultural perception of the Batak ethnic group on maternal health.

\section{Methods}

\section{Approach}

This study applied a qualitative research approach [9] because the socio-cultural context needs to explore problems that reveal the information behind 
the problem. To collect the necessary information, the researchers managed the method of Focus Group Discussion (FGD) and in-depth interviews.

\section{Settings}

This research was conducted in Sipahutar District, a rural area in North Tapanuli Regency, North Sumatra Province. The research area is $8 \mathrm{~h}$ by road from the provincial capital (Medan), and $1 \mathrm{~h}$ by car from the district capital. This location is inhabited by almost $100 \%$ by the Batak people. In general, people work as rice and corn farmers, and grow coffee and pineapples on community-owned plantations. Nearly, $100 \%$ of the tribes in the study area are Toba Bataks.

\section{Participants}

Participants in the FGDs were husbands of pregnant wives. A total of three FGD's groups were conducted to collect husbands' views on reproductive health, with a total of 30 husbands participating. In addition, a FGD was conducted by gathering health workers working at the Sipahutar District Health Center, together with seven officers from the Health Office.

FGDs in the husband's group were conducted at the Village Hall and at the Church. The FGDs lasted for approximately $3 \mathrm{~h}$ each session, using an interview guide that had been prepared by the researcher. The FGD questions are related to the husband's view of the division of labor in the household, the husband's view of pregnancy, the type of husband's work during pregnancy and the husband's view of his own work during pregnancy. The questions in the FGD have been prepared after receiving input from the expert.

The FGD for the group of health workers was held in the Sipahutar Health Center hall. The questions in the FGD were arranged to ask about the health profile of women in the research area, health problems of pregnant women, and the views of officers regarding the husband's role in the wife's pregnancy.

\section{Data collection}

Data were collected by recording all of the FGDs activities after first asking permission from the participants. Verbal consent was requested from each participant to ensure the privacy of the participants, after first explaining the purpose of the study and data processing procedures.

\section{Data analysis}

The data were analyzed using a thematic analysis approach after first performing a verbatim process on the data. The themes that emerged were then arranged according to the research objectives. The thematic analysis is presented in Table 1.

Table 1: Theme and sub-theme

\begin{tabular}{ll}
\hline Theme & Subtheme \\
\hline $\begin{array}{l}\text { Husbands' involvement in } \\
\text { antenatal care }\end{array}$ & $\begin{array}{l}\text { The activities of husbands and the reasons, the } \\
\text { activities of wives and the reasons, the position of } \\
\text { husbands, the position of wives and the reasons, the } \\
\text { view toward the health of wives }\end{array}$ \\
$\begin{array}{l}\text { Husbands' involvement in the } \\
\text { delivery period }\end{array}$ & $\begin{array}{l}\text { The activities of husbands and the reasons, the } \\
\text { activities of wives and the reasons }\end{array}$ \\
$\begin{array}{l}\text { Husbands' involvement in raising } \\
\text { Children }\end{array}$ & $\begin{array}{l}\text { Child education, child care, the number of children } \\
\text { and the reasons }\end{array}$ \\
\hline
\end{tabular}

\section{Ethics considerations}

Before carrying out the research, the researcher submitted the ethical permit from the Health Research Ethics Committee, the Faculty of Nursing, Universitas Sumatera Utara and was approved by number 2328/VII/SP/2021. Legal research permits were also submitted through the Head of the Research Institute and submitted to the Head of the North Tapanuli Regency District Health Office.

\section{Results}

After conducting data management, the themes emerging from the research data transcripts are as follows:

This study reveals that generally husbands often take their wives to check their pregnancy at the midwife. The schedule is determined by the wife because according to the husband, only the wife knows about it, unless they are told. However, at the Health Center, the husband only waits outside the Health Center. The dialogue with the FGD participants is presented below:

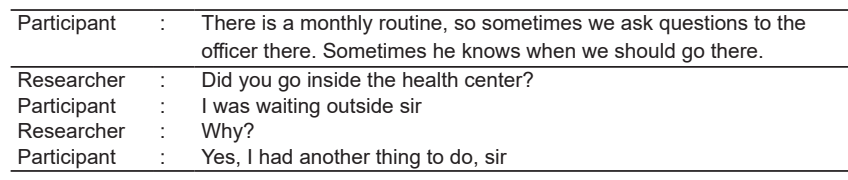

The husband feels that even taking his wife with him is enough because it is his wife's business to check her pregnancy.

This study reveals the husband's activities, which are more private in the family. Some husbands said that they wash clothes when their wives give birth. However, the problem behind it is presented below.

From the dialogue above, it can be seen that many husbands feel that they do not have the responsibility to help their wives. This is of course closely related to their position as men.

One of the husband's excuses is that they must also work. The husbands said that they were tired after working, "Tired. It's no longer possible for us to wash clothes, wash dishes. It's not possible anymore. Already 


\begin{tabular}{lcl}
\hline Researcher & $:$ & When the wife gives birth, the husband also washes clothes and \\
& & dishes? \\
\hline Participant & $:$ & Yes \\
Researcher & $:$ & For how many days? \\
Participant & $:$ & For a month, Sir \\
Researcher & $:$ & The husband helps only during the childbirth? \\
Participant & $:$ & Because that's usually the wife's job \\
Researcher & $:$ & The wife's job is to wash clothes and dishes? How did you know to \\
& & decide this job division? \\
Participant & $:$ & From a long time ago, Sir \\
Researcher & $:$ & Who determined the job division? \\
Participant & $:$ & The ancestors \\
Researcher & $:$ & Why don't the men here want to wash clothes and dishes? \\
Participant & $:$ & We have to work. We're earning money \\
Researcher & $:$ & You won't have enough money if your time is used for washing \\
& & clothes and dishes? \\
Participant & $:$ & If we do the washing, Sir, we won't have time to work, Sir \\
\hline
\end{tabular}

\begin{tabular}{lll}
\hline Researcher & $:$ & Why don't men help their wives with their work? \\
\hline Participant & $:$ & Later, I will be called as a husband who is controlled by his wife \\
Researcher & $:$ & Why is that? \\
Participant & $:$ & I will feel ashamed with the neighbors \\
Researcher & $:$ & What will the neighbors say? \\
Participant & $:$ & They would tell me to wear a skirt, Sir \\
Researcher & $:$ & Have you ever heard that expression here? To tell someone to wear \\
& a skirt \\
Participant & $:$ & Yes I have \\
Researcher & $:$ & Don't you wash clothes at home? That means people don't see you \\
Participant & $:$ & It doesn't matter, Sir. If you are drying the clothes the next morning, \\
& people will see you, Sir \\
\hline
\end{tabular}

feeling sleepy." These reasons illustrate that men are actually less involved in pregnancy because they feel that they are male humans (not supposed to do female tasks). If we look closely, actually these reasons are closely related to the self-assessment as a man. This patriarchal sentiment is seen when discussing the importance of having a son. The dialog below shows this sentiment.

\begin{tabular}{|c|c|c|}
\hline Researcher & : & Is it important here that a husband and wife must have a son? \\
\hline Participant & : & Very important \\
\hline Researcher & : & $\begin{array}{l}\text { Why do you think it's important? Why is having a boy considered } \\
\text { important? }\end{array}$ \\
\hline Participant & : & As an heir \\
\hline Participant & : & Siboan goar (Batak language, meaning=name bearer) \\
\hline Researcher & : & As a name carrier? \\
\hline Participant & : & Yes, God will search for the boy. \\
\hline Researcher & : & $\begin{array}{l}\text { God will search for the boy? Up to how many children will you keep } \\
\text { trying to have a boy for the sake of God? }\end{array}$ \\
\hline Participant & : & We keep trying until we are old. \\
\hline Researcher & : & Until you are old? Until your wife cannot be pregnant anymore? \\
\hline Participant & : & Yes \\
\hline Researcher & : & $\begin{array}{l}\text { In this region, how many children a family has because they want to } \\
\text { have a boy? }\end{array}$ \\
\hline Participant & : & 7 \\
\hline Researcher & : & After 7 children then they just got a boy? \\
\hline Participant & : & No, all girls \\
\hline Researcher & : & $\begin{array}{l}\text { But you said people here will keep trying until their wives cannot be } \\
\text { pregnant anymore? }\end{array}$ \\
\hline Participant & : & Yes \\
\hline Researcher & : & $\begin{array}{l}\text { Up to } 7 \text { then. That number means something, doesn't it? } \\
\text { If your first child is a daughter and then your second child is a son, } \\
\text { you will be called opung? Why is that? (Opung means grandfather) }\end{array}$ \\
\hline Participant & : & Yes \\
\hline Researcher & : & Why is that? Does your daughter mean nothing? \\
\hline Participant & : & That's been the rule from the beginning \\
\hline Researcher & : & Custom? \\
\hline Participant & : & Yes \\
\hline Researcher & : & What is the name of the custom? \\
\hline Participant & : & $\begin{array}{l}\text { We don't the name of the custom. We do not know the term. It is true } \\
\text { that girls can't carry our names, we need to have a boy for that. }\end{array}$ \\
\hline Researcher & : & Because she's going to marry someone else from a different family? \\
\hline Participant & & $\begin{array}{l}\text { Yes, maybe. We don't know. But actually there are no girls carrying } \\
\text { the family name. It must be a boy }\end{array}$ \\
\hline Researcher & : & $\begin{array}{l}\text { How do you feel if your children are all girls? What will other people } \\
\text { say about it? How do you feel as a husband or a man? }\end{array}$ \\
\hline Participant & & It hurts \\
\hline Researcher & : & It hurts you? \\
\hline Participant & : & If we die having no son, our family name will be gone forever. \\
\hline Researcher & & That's what you're afraid of? \\
\hline Participant & : & Yes, we have a tarombo (lineage) \\
\hline Researcher & : & Tarombo? That is the lineage, isn't it? \\
\hline Participant & & Yes, and it is for boys, not for girls. \\
\hline
\end{tabular}

The dialogue above provides an insight into cultural views that have taken root and become a tradition that is considered to be passed down from generation to generation, namely that men have a much higher position, are far more important, and therefore if we relate it to maternal health, men will feel their manhood lessen if they are involved in paying attention to their wives' health.

The one-sided perspective from the husbands aforementioned is supported with the information obtained from a health officer. The officer admitted that the pregnant women in Sipahutar Village are never accompanied by their husbands when they are doing the checkup in the Community Health Center. The husbands just drop them in front of the Health Center and they will either go home or wait outside. The health officers in FGDs also explained that the Batak women are not very lucky in terms of their position in a community, as they still have to do many household chores even when they are in the final trimester of their pregnancy; this happens because those chores are considered as women's responsibility. Many men even have plenty of time to be in a stall to drink tuak (alcoholic beverage) with their friends. Women are often considered unable to make decisions at home and in a community. The health officers never conduct an activity to increase the participation of husbands because there are heavy challenges that must be faced besides having no budget allocation for such an activity.

\section{Discussion}

The absence of the husband in health problems has caused an imbalance in the burden which in turn causes the handling of various health problems not to be optimal. This condition occurs for all circumstances so that it often results in an imbalance of responsibilities that have implications on women's health [10], [11].

This study reveals that husbands identify health problems as the wife's domain. Even husbands still feel that health (of their wives) should be the full responsibility of the wives. Husbands, according to Lewis et al. [12] position themselves in only "secondary roles", or only supportive roles. Because of those secondary roles in maternal health, including in the postnatal period, the main role is not carried out by men but by women, whether it is the wife or other women including the mother-in-law or the husband's sister(s). These women are considered to have a primary role in reproductive health matters. As stated by Teklesilasie et al. [13] husband and wife are considered to have different roles with their respective characteristics. The husband is considered to have the responsibility in earning family income and carry out physical burden [14], while the wife is expected to take care of things related to daily life at home. The limited role of husbands in reproductive health has something to do with cultural barriers as 
mentioned by Hailemariam [15]. Among them is the cultural view that husbands are not usually involved in matters that have long been women's affairs. It was even emphasized that if men were involved, the labor process could take even longer.

This imbalance of gender views is introduced and maintained through cultural mechanisms [16]. In almost all cultures, men and women are considered to have boundaries that must be obeyed and therefore violations of these limits will experience a kind of social punishment in the form of ridicule from society [17], and even a husband is accused of being controlled by his wife or under the control of his wife [18], [19]. This cultural construction clearly distances husbands from maternal health needs.

In the view of the participants of this study, men have indeed a much higher position. This can be seen in the tradition of the Batak tribe, where the existence of a son is considered important because it is considered to continue the male clan. The Batak tribe has a tradition of two names, namely the name given by their parents (surname) and the family name, which is a name that is passed down from generation to generation. All children will get this surname, but only boys are considered to be carriers of the family name because the girl's family name will be lost due to the marriage with her husband. This family name will be attached not only to the father of the child, but also to the grandfather of the child. Even though a girl has been born as the first child to a family, and her grandfather has been called by that girl's name, but if a boy is later born, then the name calling to his grandfather will automatically change, following the boy's name. That is how the Batak tribe builds traditions that have implications for the view that the position of men is far more valuable than that of women, so they must remain their roles. Likewise, traditional discussions, especially marriage, the position of speakers and delegates representing the community, are carried out by men. All of these have been rooted in the social life of the Batak people.

The above cultural ecosystem is clearly less favorable to women. This tightly regulated domain causes men to have less space to be involved in helping their wives. Even the gender imbalance that occurs causes the deterioration of women's health and even domestic violence to happen.

The Indonesian Ministry of Health has set a target of reducing maternal mortality to 183 per 100 thousand live births in 2024 [7]. However, one thing that is very important and needs improvement is that efforts to improve maternal health are still often dominated by policies that prioritize women. In other words, the approach to improving maternal health to mobilize husband's participation is still very minimal [20]. Ganle criticizes that this is indeed one of the reasons for the low involvement of husbands [19]. It must be admitted that for health workers, involving the wife alone has practical reasons. However, as a result, husbands do not feel the need to be involved in pregnancy, because they are justified that pregnancy is only a matter for pregnant women or women.

Therefore, investigating husbands' views and then involving them in future interventions are important and should not be separated from efforts to design health promotion strategies that aim to improve the health of pregnant women [21], [22] while at the same time, the wife should also be given the same understanding because this cultural view also affects both sexes [23].

This process should be carried out using appropriate cultural social channels. Involving the community slowly through proper health education will provide results that may be more positive than changing the customs that have long been implemented by the community.

\section{Conclusion}

This study shows that the role of husbands in reproductive health, especially when their wives are pregnant, is still low. This is due to the cultural view that places men in a higher position than women, thus keeping men away from jobs that are considered to be women's affairs. Efforts are needed to change the cultural views of society.

\section{Acknowledgment}

Researchers thank the local government, especially the District Health Office of North Tapanuli Regency for permission to carry out this research, including the Head of the Sipahutar District Health Center together with the field staff who have supported the data collection.

\section{References}

1. World Health Organization. World Health Organization WHO Recommendations on Health Promotion Interventions for Maternal and Newborn Health. Geneva: World Health Organization; 2015.

2. Say L, Chou D, Gemmill A, Tunçalp O, Moller AB, Daniels J, et al. Global causes of maternal death: A WHO systematic analysis. Lancet Glob Health. 2014;2(6):323-33. 10.1016/ S2214-109X(14)70227-X

PMid:25103301

3. World Health Organization. Maternal Mortality. Geneva: 
World Health Organization; 2019. Available from: https://www. who.int/news-room/fact-sheets/detail/maternal-mortality [Last accessed on 2021 Aug 27].

4. Zaluchu F. Gender Inequality, Behind Maternal Mortality in Nias Island, North Sumatra, Indonesia. Amsterdam: University of Amsterdam; 2018.

5. Rahman $A E$, Perkins J, Islam $S$, Siddique $A B$, Moinuddin $M$, Anwar MR, et al. Knowledge and involvement of husbands in maternal and newborn health in rural Bangladesh. BMC Pregnancy Childbirth. 2018;18(1):247. https://doi.org/10.1186/ s12884-018-1882-2

PMid:29914410

6. Singh D, Lample M, Earnest J. The involvement of men in maternal health care: Cross-sectional, pilot case studies from Maligita and Kibibi, Uganda. Reprod Health. 2014;11(1):68. https://doi.org/10.1186/1742-4755-11-68 PMid:25192714

7. Kemenkes, Peraturan Menteri Kesehatan RI No. 21 tahun 2020 Tentang Renstra Kemenkes Tahun 2020-2024. Kemenkes, Peraturan Menteri Kesehatan; 2020.

8. BPS Sumut. Sumatera Utara Sumatera Utara. BPS Sumut; 2021.

9. Zaluchu F. Metodologi Penelitian Kesehatan. Bandung: Cipta Pustaka Media; 2006.

10. Sarumpaet S, Hutahaean MM, Zaluchu F. An analysis of factors affecting pregnant woman's use of prevention of mother-to-child transmission services in urban setting. Indian J Public Health Res Dev. 2018;9(10):780-5.

11. Eyanoer PC, Zaluchu F. COVID-19 and the fourth burden of women in developing countries: A mini review. Open Access Maced J Med Sci. 2020;8:476-9. https://doi.org/10.3889/ oamjms.2020.5470

12. Lewis $S$, Lee A, Simkhada P. The role of husbands in maternal health and safe childbirth in rural Nepal: A qualitative study. BMC Pregnancy Childbirth. 2015;15:162. https://doi.org/10.1186/ s12884-015-0599-8 PMid:26239123

13. Teklesilasie W, Deressa W. Barriers to husbands' involvement in maternal health care in Sidama zone, Southern Ethiopia: A qualitative study. BMC Pregnancy Childbirth. 2020;20(1):21. https://doi.org/10.1186/s12884-019-2697-5 PMid:31906876

14. Mkandawire E, Hendriks SL. The role of the man is to look for food: Lessons from men's involvement in maternal and child health programmes in rural Central Malawi. PLoS One. 2019;14(8):e0221623. https://doi.org/10.1371/journal. pone. 0221623

PMid:31442269
15. Hailemariam S, Abayneh M, Genetu A. Individual, socio-cultural and health facility factors affecting men's involvement in facilitybased childbirth in Southwest, Ethiopia: A mixed method study. SAGE Open Med. 2021;9:20503121211023367. doi: https://doi. org/10.1177/20503121211023367 PMid:34178338

16. Maluka S, Japhet $P$, Fitzgerald $S$, Begum $K$, Alexander $M$, Kamuzora P. Leaving no one behind: Using action research to promote male involvement in maternal and child health in Iringa region, Tanzania. BMJ Open. 2020;10:e038823. https://doi. org/10.1136/bmjopen-2020-038823.

17. Mkandawire E, Hendriks SL. A qualitative analysis of men's involvement in maternal and child health as a policy intervention in rural Central Malawi. BMC Pregnancy Childbirth. 2018;18(1):37. https://doi.org/10.1186/s12884-018-1669-5 PMid:29351778

18. Gibore NS, Bali TA. Community perspectives: An exploration of potential barriers to men's involvement in maternity care in a central Tanzanian community. PLoS One. 2020;15(5):e0232939. https://doi.org/10.1371/journal.pone.0232939

19. Ganle JK, Dery I. What men don't know can hurt women's health': A qualitative study of the barriers to and opportunities for men's involvement in maternal healthcare in Ghana. Reprod Health. 2015;12:93. https://doi.org/10.1186/ s12978-015-0083-y PMid:26452546

20. Ongolly FK, Bukachi SA. Barriers to men's involvement in antenatal and postnatal care in Butula, Western Kenya. Afr J Prim Health Care Fam Med. 2019;11(1):e1-7. https://doi. org/10.4102/phcfm.v11i1.1911

PMid:31368318

21. Isler J, He N, Adam M, Sie A, Mcmahon SA. If he sees it with his own eyes, he will understand: How gender informed the content and delivery of a maternal nutrition intervention in Burkina Faso. Health Policy Plan. 2020;35(5):536-45. https://doi.org/10.1093/ heapol/czaa012

PMid:32106288

22. Gopal P, Fisher D, Seruwagi G, Taddese HB. Male involvement in reproductive, maternal, newborn, and child health: Evaluating gaps between policy and practice in Uganda. Reprod Health. 2020;17(1):114. https://doi.org/10.1186/s12978-020-00961-4 PMid:32718357

23. Greenspan JA, Chebet JJ, Mpembeni R, Mosha I, Mpunga M, Winch PJ, et al. Men's roles in care seeking for maternal and newborn health: A qualitative study applying the three delays model to male involvement in Morogoro Region, Tanzania. BMC Pregnancy Childbirth. 2019;19:293. https://doi.org/10.1186/ s12884-019-2439-8 